\title{
EFFECT OF TILTING ON THE CARDIOVASCULAR RESPONSES AND PLASMA CATECHOLAMINE LEVELS IN SPINAL MAN
}

\author{
By L. Guttmann, A. F. Munro, R. Robinson and J. J. Walsh \\ National Spinal Injuries Centre, Stoke Mandeville Hospital, Aylesbury, Bucks, England
}

HILl (I895) studied the circulatory changes produced by passive tilting in spinal dogs, and showed the importance of the splanchnic system in maintaining homoeostasis in the vertical position; but there have been few experimental studies in the spinal man. Guttmann (1946, 1953), Jonason (1947), Guttmann and Whitteridge (1947), Cunningham et al. (1953), analysed the effects in paraplegics and quadriplegics of postural change due to rapid tilting from the horizontal to the upright position, by recording pulse rates, systolic and diastolic blood pressures, blood flow and subjective sensations. In patients with complete high thoracic and cervical transections there was a profound maladaptation to the vertical position.

At this Centre, Munro and Robinson (I960) have shown that spinal subjects with high thoracic and cervical lesions have a significantly lower level of adrenaline and noradrenaline in the peripheral plasma than have normal subjects. It was therefore decided to examine the effect of postural changes on plasma catecholamine levels in spinal subjects and to determine whether these could be related to the cardiovascular changes.

\section{METHODS}

Patients with different levels of cord lesion were moved on a tilting table and maintained in the vertical position for sufficient time to produce syncope in the majority of cases. For comparison, measurements were made in a number of normal and spinal subjects held in the erect position for two minutes without fainting so as to show the effect of posture as distinct from any changes associated with fainting.

All the subjects were accustomed to blood sampling and to hospital routine. Before being moved on to the tilt table they were given an explanation of the procedure, told what might happen and asked to describe their sensations for as long as possible while tilted vertically. With the subject supine on the table, the bladder was catheterised and emptied to prevent distention affecting the blood pressure (Guttmann \& Whitteridge, 1947). A sorbo rubber pad was placed high on the chest; the straps attached to each side of the title table at chest level were then taken up from below each axilla and secured over the pad in order to prevent the patient slipping downwards when the table was tilted. The wrists were loosely tied together with tape to prevent the arms from slipping over the side of the table. A two-inch thick rubber pad was placed between the feet and the lower board and another between the head and the top board of the table. For blood pressure recording the rubber cuff of the sphygmomanometer was placed in position round the upper part of the left arm. For ECG recording, leads I were used from a portable direct writing machine; and for blood sampling a Mitchell's intravenous self-sealing needle was introduced into a dorsal vein in the wrist and kept clear by flushing with saline between sampling. During an experiment one member of the team timed and made a record of events and procedures, noted the reactions 
and comments of the patient and was responsible for tilting the table at the appropriate time. Another measured blood pressure throughout the experiment; the third was responsible for making pulse rate and ECG records and the fourth took the blood samples at the required times.

The subject remained in the supine position for about 30 minutes before being tilted. During this time an ECG record and a blood sample were taken and blood pressure and pulse rate measured. Continuous ECG recordings were made starting from the time when the subject was tilted vertically and continued until he was tilted back to the horizontal and had recovered from the effects of the vertical posture. The time elapsing before the plasma sample indicating the response to the vertical tilting was taken depended upon how long this position could be maintained without fainting occurring. If fainting did not occur, the subject was held vertically for about i 5 minutes before blood sampling and then returned to the horizontal. If it did occur within this time, the subject was returned to the horizontal immediately and then the blood was sampled. The final blood sample was taken about I 5 minutes after he had resumed the horizontal position. The subject was encouraged to describe his sensations during the procedure, particularly the premonitory signs of failing consciousness.

\section{Plasma Catecholamine Extraction and Assay Reagents}

Sodium Fluoride-Sodium Thiosulphate Solution. 2 per cent. NaF and 3 per cent. $\mathrm{N}_{2} \mathrm{~S}_{2} \mathrm{O}_{3}$ in distilled water.

Sodium Carbonate. A $0.5 \mathrm{M}$ solution in distilled water.

Sodium Acetate buffered to $\mathrm{pH} 8.4 . \quad 0.2 \mathrm{M}$ sodium acetate was passed over a column of ZeoKarb $2 \mathrm{I} 5$ and adjusted to $\mathrm{pH} 8.4$ by adding $0.5 \mathrm{~N}$ sodium carbonate solution. A glass electrode was used to aid the accurate adjustment of the $\mathrm{pH}$.

Acid-washed Alumina. Ioo g. of B.D.H. 'for chromatographic analysis' grade was stirred with $500 \mathrm{ml}$. of boiling $2 \mathrm{~N} \mathrm{HCl}$ for about 20 minutes. It was then filtered off on a Buchner funnel, washed with a further $500 \mathrm{ml}$. of $2 \mathrm{~N} \mathrm{HCl}$ and then washed repeatedly with distilled water. It was dried overnight at $100^{\circ} \mathrm{C}$. Ascorbic Acid. I per cent. in distilled water prepared fresh daily.

Acetic Acid. A $0.2 \mathrm{~N}$ solution in distilled water.

pH 3.5 Buffer. I M sodium acetate-acetic acid.

Sodium Acetate Solution. I M in distilled water.

Potassium Ferricyanide. A 0.25 per cent. solution in distilled water.

Zinc Sulphate. A 0.5 per cent. solution in distilled water.

Sodium Hydroxide Solution. 20 per cent. in distilled water.

Alkaline Ascorbate. $9 \mathrm{ml}$. of the sodium hydroxide solution was added to I ml. of ascorbic acid solution immediately before use.

Procedure. Fifteen ml. of blood was collected from the median cubital vein directly into $5 \mathrm{ml}$. of sodium fluoride-sodium thiosulphate solution in a 20-ml. syringe. With the minimum of delay the blood was centrifuged at about $500 \mathrm{~g}$ for 5 to ro minutes and the plasma separated. Such treatment yields a platelet-rich plasma (Weil-Malherbe \& Bone, I958).

To Io $\mathrm{ml}$. of the plasma was added Io $\mathrm{ml}$. of $\mathrm{pH} 8 \cdot 4$ sodium acetate buffer. The $\mathrm{pH}$ of the mixture was brought to exactly 8.4 by adding a little $0.5 \mathrm{~N}$ sodium carbonate. Precise adjustment of the $\mathrm{pH}$ was made with the aid of a glass electrode. 
Catecholamines were isolated from plasma by the method of Weil-Malherbe and Bone (1952) on micro-columns of alumina. The columns were made in $5-\mathrm{mm}$. bore glass tubing about $25 \mathrm{~cm}$. long. These carried $50-\mathrm{ml}$. separating funnels at the top end attached by short lengths of well-washed, clear, PVC tubing. The columns were mounted on boiling tubes which had side arms. The columns were made by 'slurrying in' about I g. of alumina with $5 \mathrm{ml}$. of $\mathrm{pH}$ 8.4 sodium acetate buffer. Mild suction was applied from a water pump and the rate of filtration adjusted to' 20 to 30 drops a minute. Next was added the plasma -acetate buffer followed by $5 \mathrm{ml}$. of distilled water. The catecholamines were eluted with $5 \mathrm{ml}$. of $0.2 \mathrm{~N}$ acetic acid followed by $5 \mathrm{ml}$. of distilled water.

The eluate was acidic. To bring it to $\mathrm{pH} 6.0$ - the $\mathrm{pH}$ at which both adrenaline and noradrenaline are oxidised-it was found necessary to add an equal volume of I $M$ sodium acetate solution. For practical purposes the very smal] amount of noradrenaline oxidised at $\mathrm{pH} 3.5$ can be ignored. The noradrenaline concentration is found from the difference between the total-adrenaline plus noradrenaline-determined after oxidation at $\mathrm{pH} 6.0$, and the adrenaline determined after oxidation at $\mathrm{pH} 3 \cdot 5$.

Determination of Adrenaline plus Noradrenaline. In the fluorimeter cuvette were placed:

$2 \mathrm{ml}$. eluate,

$2 \mathrm{ml}$. I M sodium acetate solution,

$0.1 \mathrm{ml} .0 .5$ per cent. zinc sulphate solution, and

$0.1 \mathrm{ml} .0 .25$ per cent. potassium ferricyanide solution.

After mixing, oxidation was allowed to proceed for three minutes. Then I ml. of freshly prepared alkaline ascorbate solution was added and the fluorescence $(A)$ measured after exactly two minutes.

To account for any fluorescence which might be present other than from the trihydroxyindoles, a 'faded blank' was prepared; $2 \mathrm{ml}$. of the eluate was treated as before, but I ml. of 20 per cent. sodium hydroxide solution was added instead of alkaline ascorbate. In the absence of ascorbic acid the fluorescence due to the trihydroxyindoles faded completely in less than two minutes (Euler \& Floding, 1955). The remaining fluorescence was determined as before $(B)$.

Two reagent blanks were prepared using $2 \mathrm{ml}$. of distilled water instead of $2 \mathrm{ml}$. of eluate. The first contains $\mathrm{I} \mathrm{ml}$. of alkaline ascorbate and the second I $\mathrm{ml}$. of 20 per cent. sodium hydroxide solution. Let the fluorimeter readings be $C$ and $D$ respectively.

The fluorescence equivalent of the adrenaline plus noradrenaline in the sample is $(A-C)-(B-D)$. Let this be $T$.

Two $\mathrm{ml}$. of a freshly prepared solution containing $0.02 \mu \mathrm{g}$. of noradrenaline were treated in the same way as the eluate. The reading of the appropriate blank is subtracted from the fluorimeter reading for this standard solution. Let the resulting reading be $r$.

Determination of Arenaline. The procedure for determining adrenaline was exactly the same as that for determining the total of adrenaline plus noradrenaline except that the $\mathrm{pH} 3.5$ buffer was used instead of the $\mathrm{pH} 6.0$ (I M sodium acetate solution). Let the fluorescence equivalent of the adrenaline in $2 \mathrm{ml}$. of eluate be $A d$. 
Two ml. of a freshly prepared solution containing $0.02 \mu \mathrm{g}$. of adrenaline in $0.01 \mathrm{~N} \mathrm{HCl}$ were put through the same procedure using the $\mathrm{pH} 3.5$ buffer. The fluorescence was determined as before and the fluorimeter reading of the appropriate blank subtracted. Let the resultant fluorimeter reading for the adrenaline standard be $R$.

Calculation. The plasma is diluted $4 / 3$ times by the sodium fluoridesodium thiosulphate solution.

Thus, adrenaline: $\frac{A d}{R} \times 0.02 \times \frac{4}{3} \times \frac{1000}{2} \mu \mathrm{g}$. per litre plasma, and, noradrenaline: $\frac{T-A d}{r} \times 0.02 \times \frac{4}{3} \times \frac{1000}{2} \mu \mathrm{g}$. per litre plasma.

Measurement of Fluorescence. The fluorimeter used was made specially for the purpose by Dr. F. D. Stott of the Medical Research Council's Electromedical Research Unit. To achieve the necessary sensitivity, a photomultiplier tube was used in the fluorimeter. Errors due to fluctuations in the photomultiplier dark current were eliminated by using a single photomultiplier and a switched light beam. Thus the same phototube was used to compare the fluorescence of the solution to be measured with a standard in much the same way as in a switchedbeam spectrophotometer.

It was possible with this instrument to shunt off the blank and this greatly increased the sensitivity. The primary filter was a Kodak No. I which has a wavelength of maximum transmission at $430 \mathrm{~mm}$. An Ilford 625 was used as secondary filter. Besides being completely non-fluorescent, the Ilford 625 has a sharp cut-off below $500 \mathrm{~mm}$.; this eliminates the possibilities of fluorescence due to contaminating plasma proteins.

Validity of the Assay Method. To investigate the specificity and precision of the method, recovery experiments were carried out. Mixed solution of adrenaline and noradrenaline were added to fresh blood bank plasma to produce concentrations of from I to $50 \mathrm{mg}$. total catecholamine per litre. The solutions so produced were assayed as described above.

The mean recovery of adrenaline was 96.25 per cent. (s.d. I2.5 per cent.) and of noradrenaline 88.9 per cent. (s.d. 6.6 per cent.). These recoveries are rather lower and more variable than those found by Weil-Malherbe and Bone (I952), the authors of the method of isolation used. Nevertheless, they indicate a good recovery of each amine and satisfactory reproductibility.

Further confirmation of the method of measuring adrenaline was obtained by carrying out parallel biological and fluorimetric assays on blood specimens collected from two patients and from two cats in the early stages after spinal cord transection. In these circumstances, the level of adrenaline in the peripheral plasma is high enough to be measurable by biological methods; unfortunately, noradrenaline levels are too low to permit biological assay.

Some of the adrenaline assays were made after the catecholamines were separated chromatographically by the method of Crawford and Gutschoorn (I95I) The amines are completely resolved by this technique.

Biological determinations of adrenaline were carried out by the method of de Jalon et al. (1945) using the virgin rat uterus as test object. An automatic 
apparatus similar to that described by Gaddum and Lembeck (1949) was used.

Table I summarises the results obtained.

\section{TABLE I}

Parallel Biological and Fluorimetric Assays of Plasma Adrenaline on Subjects in Spinal Shock

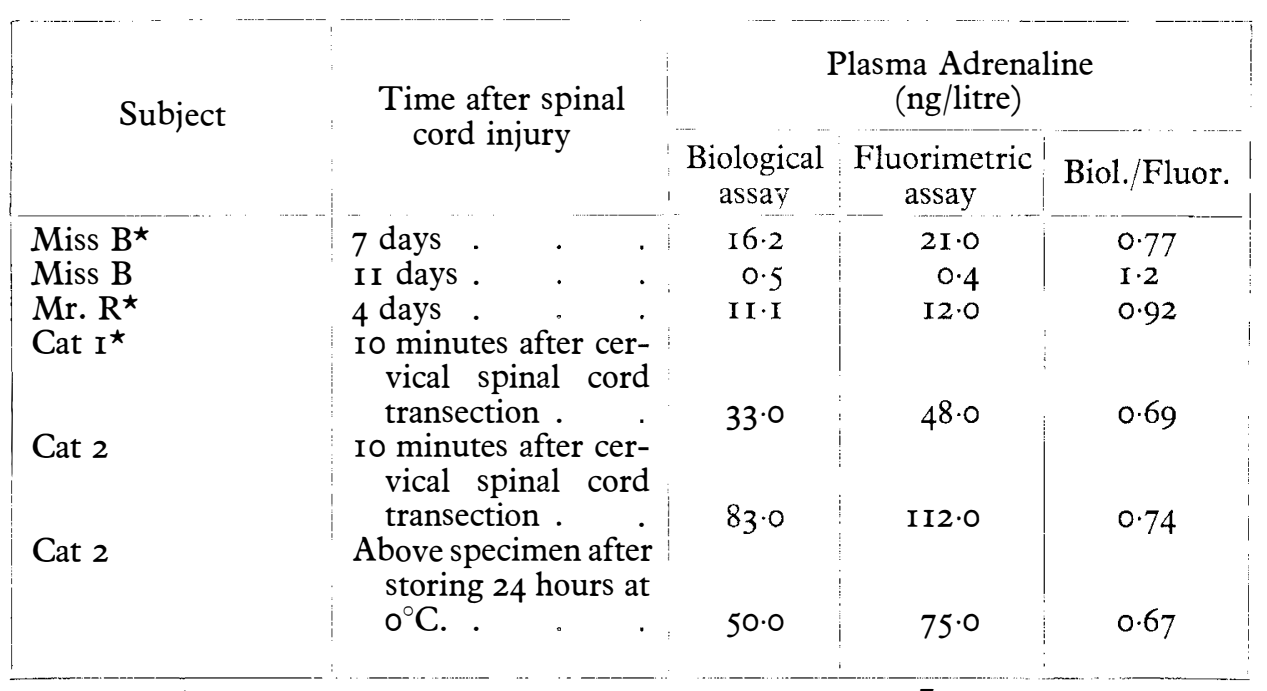

* Catecholamines separated chromatographically $\quad \bar{X}=0.83 \pm 0.22$

The criteria fulfilled by this method which determined the substance as adrenaline are:

(a) It gives the highly specific fluorescence reaction which is used to determine it.

(b) It travels on chromatograms with the $\mathrm{Rf}$ value of adrenaline.

(c) It inhibits the acteyl-choline-induced contractions of the rat uterus.

(d) Good agreement is found between the results of biological and fluorimetric assay.

The nature of these criteria leave little doubt that the substance determined as adrenaline is, in fact, adrenaline.

\section{RESULTS}

Signs and Incidence of Fainting. The invariable premonitory symptoms of syncope in spinal subjects after vertical tilting were blurring and finally loss of vision. Giddiness, buzzing and ringing in the ears were less frequently mentioned. Tingling in the hands was complained of by two patients and headache by one patient whilst in the vertical position. Sweating was mentioned by one patient and nausea was complained of in two cases by patients who lost consciousness, but this symptom only occurred after they had resumed the horizontal position. Vomiting never occurred. Those who fainted became paler whilst held in the vertical position, but on being returned to the horizontal showed facial flushing which was particularly marked in the subjects with cervical lesions. 
The patients who retained consciousness and appeared normal during the vertical tilt made no complaints.

The incidence of fainting and the time required, after assuming the vertical position, for fainting to occur in patients with different levels of lesion is summarised in Table II. The three subjects with complete cervical lesions lost consciousness after being tilted and in the I I tests involving lessions at levels from the upper to the mid-thoracic region of the cord unconsciousness occurred after tilting in all except one, a subject with a complete lession at T6. With lesions of the lower thoracic region consciousness was lost in three out of nine tests. Fainting occurred in four of the eight tests on subjects with incomplete cervical lesions. On the average, fainting occurred earlier in the groups with the higher levels of lesion, but within each group there was much variability and no apparent relation between the level of the lesion and the time for which consciousness could be maintained in the vertical position. When more than one test was performed on the same subject, fainting could occur at one time and not the other. When it occurred on both occasions the time elapsing before the faint could differ widely. The data indicate that with complete spinal lesions above T6 fainting is likely to occur if the subject is kept in the completely vertical position for more than two to three minutes.

TABLE II

Incidence of Fainting in Spinal Subjects Tilted to the Vertical Position

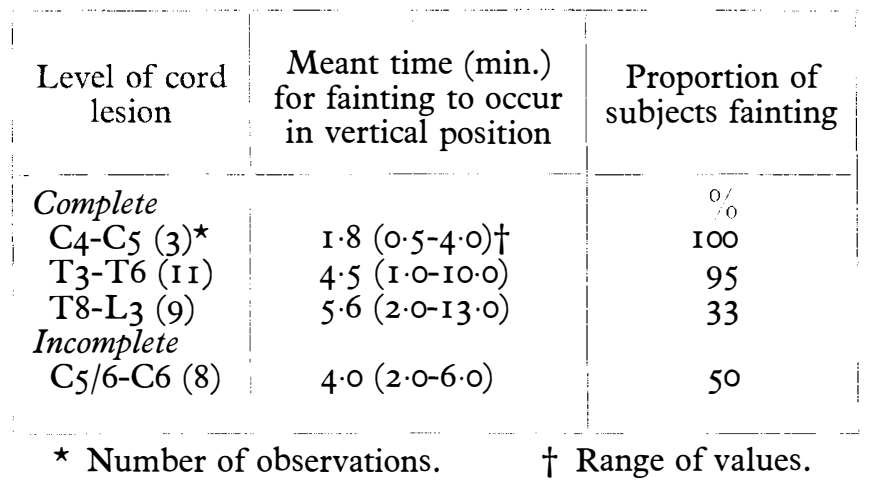

Blood Pressure and Heart Rate. The response to tilting vertically depended on whether consciousness was retained in the vertical position. Wher it was retained there was a small, transient but sometimes sustained increase of heart rate and systolic pressure and a maintained rise of diastolic pressure as shown in Figure $\mathrm{I} f$. For comparison the responses of four subjects who fainted are shown graphically in Figures $\mathrm{I} a$-I $d$. An immediate increase of heart rate in the vertical position usually persisted after consciousness was lost, while simultaneously systolic and diastolic pressure fell and became unrecordable. The blood pressure in recumbent cervical patients was similar to that of the normal or low spinal subjects, but with tilt to the vertical the blood pressure fell below the recordable value more rapidly than in subjects with lower levels of lesion. Within the groups, however, there was no correlation between the level of the lesion and the rate of fall of blood pressure consequent on assuming the vertical position. The rate of fall of blood pressure to an unrecordable level is also poorly correlated 
I(a) CERVIC. 4

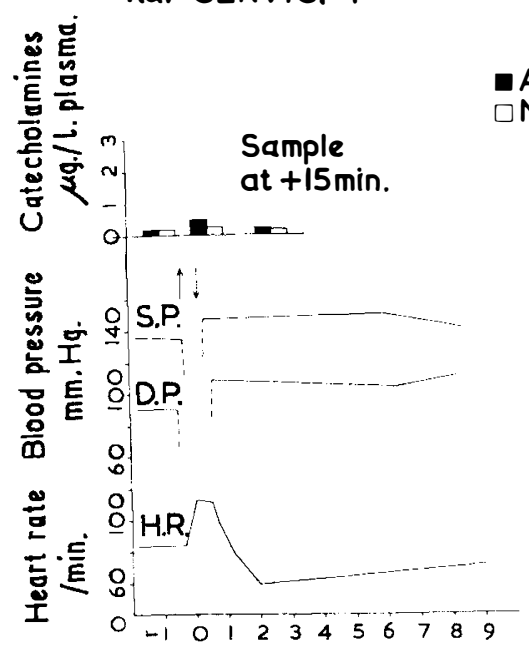

I(b) THORAC. 4/5

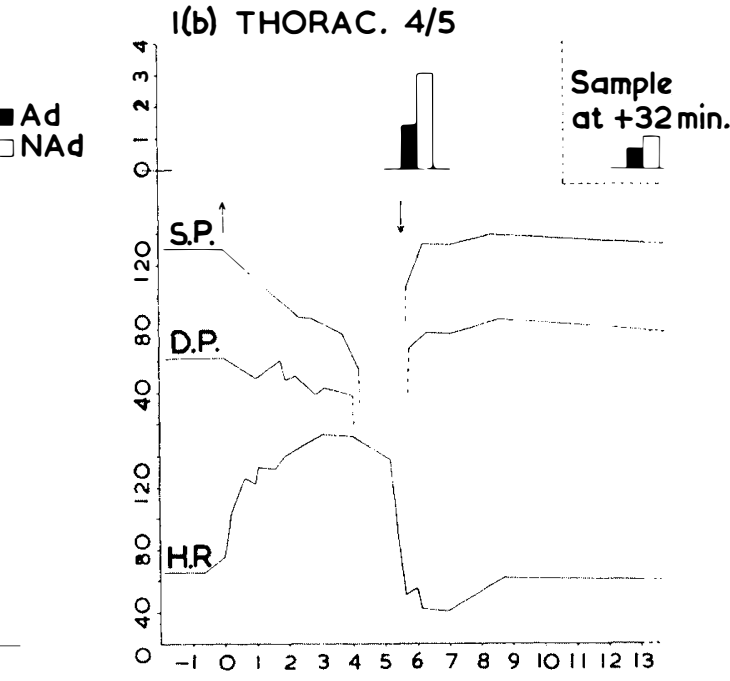

Time (min) from time (o) of tilting.

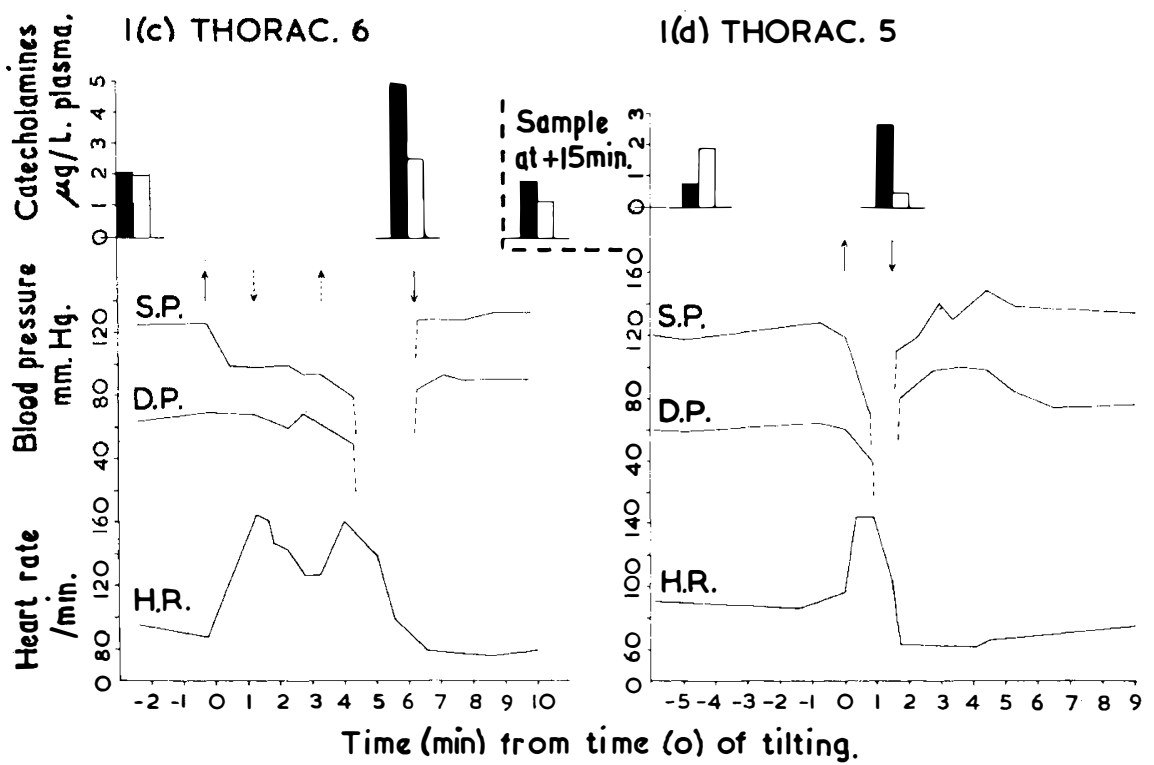




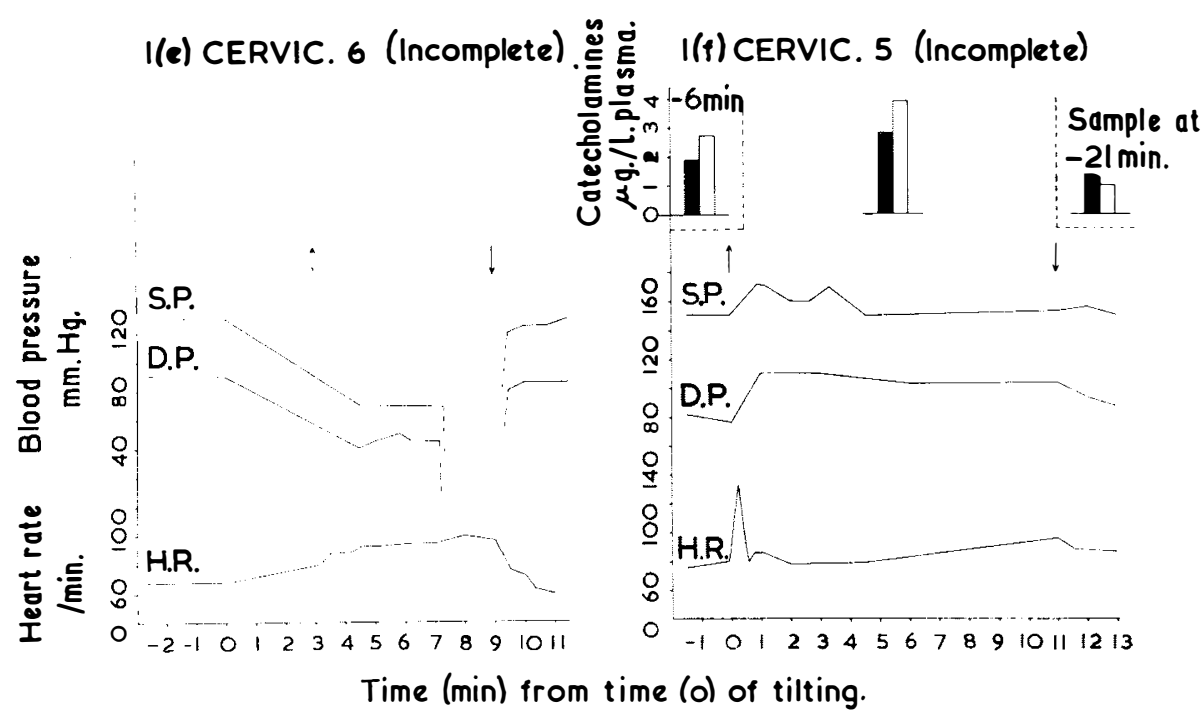

FIG. I

Shows heart rate (H.R.), systolic pressure (S.P.), diastolic pressure (D.P.) and catecholamine changes in paraplegic subjects before, during and after being tilted vertically on a tilt table. The arrows indicate tilt to the vertical $(\uparrow)$ and return to the horizontal position $(\downarrow)$. Plasma adrenaline values are shown $\square$ and noradrenaline $\square$. Figure I $(a)$ : Male aged 25 with complete $\mathrm{C}_{4}$ lesion, sustained $\mathrm{I}_{3}$ weeks earlier: fainted in upright position. Figure I $(b)$ : Male aged 20 with complete $\mathrm{T}_{4} / 5$ lesion, sustained 8 weeks earlier: fainted in upright position. Figure I (c): Male aged I 8 with complete T6 lesion of I 7 weeks' duration: fainted in upright position. Figure I $(d)$ : Male aged 24 with complete $\mathrm{T}_{5}$ lesion of $\mathrm{I} 7$ weeks' duration: fainted in upright position. Figure I (e): Female aged 25 with incomplete C6 lesion but extensive paralysis: lesion of 17 weeks' duration: did not faint in upright position. Figure $\mathbf{I}(f)$ : Male aged 19 with incomplete lesion at $\mathrm{C}_{5} / 6$ : moderate paralysis of I3 weeks' duration: did not faint in upright position.

with the resistance to fainting. This is illustrated in the three cervical patients in whom a rapidly unrecordable blood pressure after tilting vertically was compatible with consciousness for half, three-quarters and four minutes respectively.

A sustained bradycardia, again not related in degree to the level of the lesion, occurred during recumbency following return from the vertical to the horizontal position after return of consciousness in almost every case and was invariably associated with blood pressure values above the normal (table III). This was not found in patients who did not faint.

Electrocardiograph Records during Tilting and Syncope. The recordings were made with leads I only, since the main object was to obtain a continuous record of heart rate. The beat showed a transient irregularity in the post-tilt position (fig. $2 a$ ) in some patients who fainted. The main change observed with the subjects in the vertical posture was fusion of $\mathrm{P}$ and $\mathrm{T}$ waves due to the cardiac acceleration. Depression of the ST segment occurred in four patients when consciousness was lost (fig. $2 b$ ).

Plasma Catecholamines. Peripheral plasma samples taken from patients when they were lying down usually contained less adrenaline than noradrenaline. 


\section{TABLE III}

Blood Pressure and Heart Rate Changes in Spinal Subjects Fainting after being Tilted Vertically

\begin{tabular}{|c|c|c|c|c|c|c|}
\hline \multirow[b]{2}{*}{$\begin{array}{l}\text { Level of cord } \\
\text { lesion }\end{array}$} & \multirow{2}{*}{$\begin{array}{l}\text { Mean time } \\
\text { (min.) in ver- } \\
\text { tical position } \\
\text { before blood } \\
\text { pressure } \\
\text { becomes } \\
\text { unrecordable }\end{array}$} & \multicolumn{2}{|c|}{$\begin{array}{l}\text { Systolic/diastolic } \\
\text { bl. pressure }(\mathrm{mm} . \mathrm{Hg})\end{array}$} & \multicolumn{3}{|c|}{ Heart Rate per min. } \\
\hline & & $\begin{array}{l}\text { Before } \\
\text { tilt } \\
\text { to vertical } \\
\text { position }\end{array}$ & $\begin{array}{c}\text { After } \\
\text { tilt } \\
\text { from } \\
\text { vertical to } \\
\text { horizontal } \\
\text { position }\end{array}$ & $\begin{array}{l}\text { 'Before } \\
\text { tilt } \\
\text { (vert.) }\end{array}$ & $\begin{array}{l}\text { Maximum } \\
\text { during } \\
\text { tilt } \\
\text { (vertical) }\end{array}$ & $\begin{array}{c}\text { After } \\
\text { tilt } \\
\text { (horizontal) }\end{array}$ \\
\hline Complete & & & & & & \\
\hline $\mathrm{C}_{4}-\mathrm{C}_{5}(3)^{\star}$ & $\begin{array}{c}0.4 \\
(0.3-0.8) \dagger\end{array}$ & I I $7 / 72$ & I $45 / 92$ & $7 \mathrm{I}$ & I I 5 & 53 \\
\hline T3-T6 (I0) & $\begin{array}{c}3 \cdot 3 \\
(0.3-6 \cdot 0)\end{array}$ & I $24 / 75$ & I36/89 & 78 & II 2 & 59 \\
\hline Tio-Ti2 (2) & $\begin{array}{c}(0.3-0 \cdot 0) \\
2 \cdot 7 \\
(0.3-10 \cdot 0)\end{array}$ & I I $7 / 74$ & I $26 / 85$ & 73 & I07 & 57 \\
\hline $\begin{array}{l}\text { Incomplete } \\
\mathrm{C} 5 / 6-\mathrm{C} 6(4)\end{array}$ & $\begin{array}{c}I \cdot 7 \\
(0 \cdot 3-3 \cdot 0)\end{array}$ & I 27/70 & I $30 / 85$ & 67 & II 3 & $5 \mathrm{I}$ \\
\hline & $\ldots \ldots$ & $\ldots$ & & - & & $\ldots \ldots$ \\
\hline
\end{tabular}

This agrees with the results previously found in normal resting subjects (Munro \& Robinson, 1960). With the assumption of the vertical position the total catecholamine content of the plasma increased in all except three of the subjects. Figure 3 shows the plasma catecholamine changes in normal subjects and in spinal patients who did not faint when they were held in the standing position for two minutes. The greatest increment was found in normal subjects. In patients with progressively higher levels of lesion the catecholamine response to holding the vertical posture diminished until, in cervical patients, it was virtually absent. Both adrenaline and noradrenaline contributed to the increase, with noradrenaline predominating. Figure $4 a$ shows a similar type of response in patients who were passively tilted and held vertically for I 5 minutes but did not faint. The noradrenaline component again predominated, whatever the level or completeness of the lesion.

In comparison, the plasma catecholamine changes of the subjects with complete spinal lesions who fainted after passive tilt to the vertical (fig. $4 b$ ) showed a marked degree of inconsistency. The procedure often produced a much greater increase of adrenaline than noradrenaline in the plasma and the total catecholamine values were usually in excess of what might be expected for the level of the lesion. The response was similar in the three patients with incomplete lesions who fainted and who had pre- and post-tilt plasma catecholamine values much in excess of those usually found in patients with corresponding levels of complete lesion. 
FIG. $2(a)$

Thorac. 5 lesion

Pre-tilt supine position.

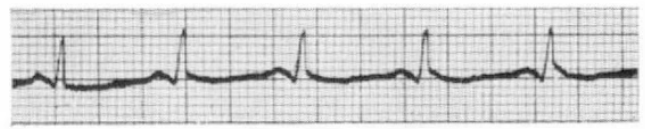

Conscious in upright position.

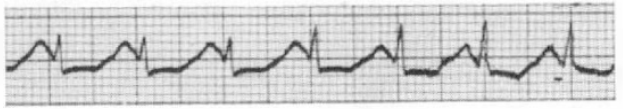

Fainting in upright position.

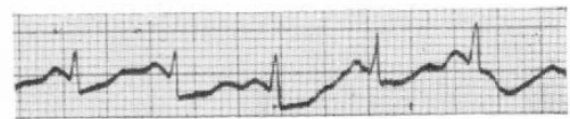

Recovery in Posttilt supine position.

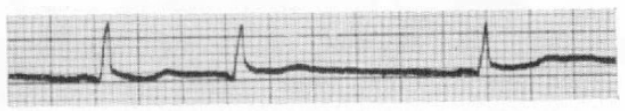

FIG. $2(b)$

Thorac. 4 lesion

Pre-tilt supine position.

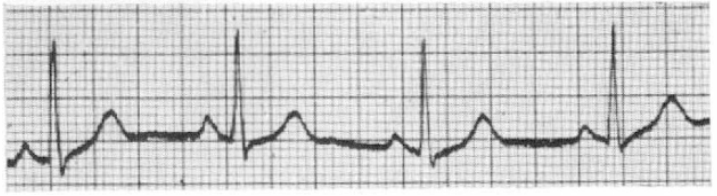

Fainting in upright position.

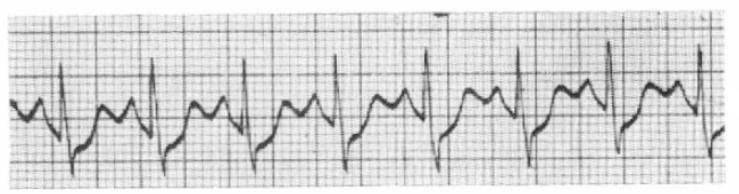

Recovery in Post-tilt supine position.

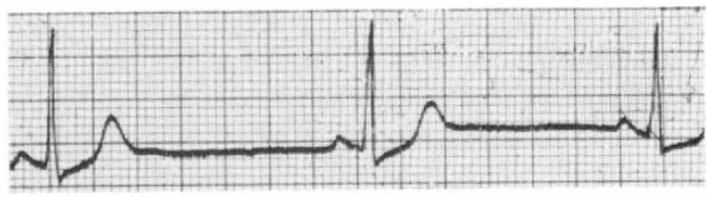

FIG. 2

Shows the ECG records (leads I) from two spinal subjects who fainted when tilted upright. (a) Male patient, aged 20, with $\mathrm{T}_{5}$ lesion for 25 weeks; (b) Male patient, aged 20, with $\mathrm{T}_{4} / 5$ lesion for eight weeks. 


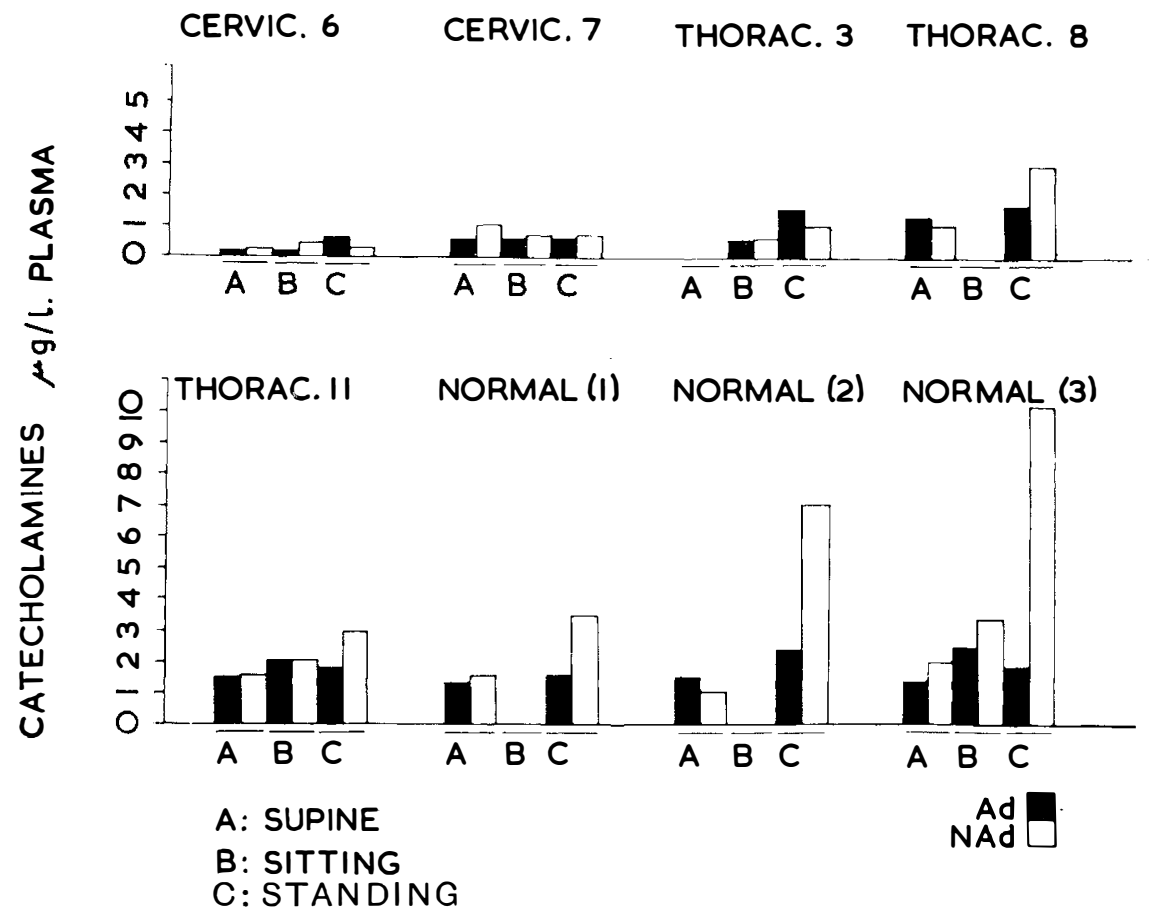

FIG. 3

Shows the adrenaline and noradrenaline values in the peripheral plasma of normal and paraplegic subjects with different levels of lesion $(A)$ supine, $(B)$ seated and $(C)$ standing or held vertically for 2 minutes. Adrenaline values are shown $\mathbf{m}$ and noradrenaline $\square$.

\section{DISCUSSION}

The present investigation shows that the incidence of fainting in subjects with lesions below the T6 level is only slightly higher than has been observed by other workers (Allen et al., I945) in normal men submitted to the same tilting procedure. On the other hand few of the spinal subjects with lesions above the T6 level were able to maintain consciousness for more than two or three minutes. The T6 level thus appears to be critical for the maintenance of the erect posture, and the reason is that considerable vasomotor regulation is still possible when the lesion is below T6, but with lesions above this level the vasomotor centre has little control over the vascular bed. The hypertensive effect produced by the distention of the urinary bladder in spinal man would also appear to be significantly related to the T6 level of the cord (Guttmann \& Whitteridge, 1947).

Transient compensation to tilting is effected by the increased heart rate, but finally cardiac output falls and hypotension is followed by loss of consciousness. A likely contributory factor is the paralysis of the muscles of the abdominal wall and lower limbs. The importance of movement and tone in these muscles for effective response to change of posture even in normal subjects has been shown by Jeffers et al. (194I). One of the three subjects with lesions below T6 who 
(a.) Subjects did not faint.

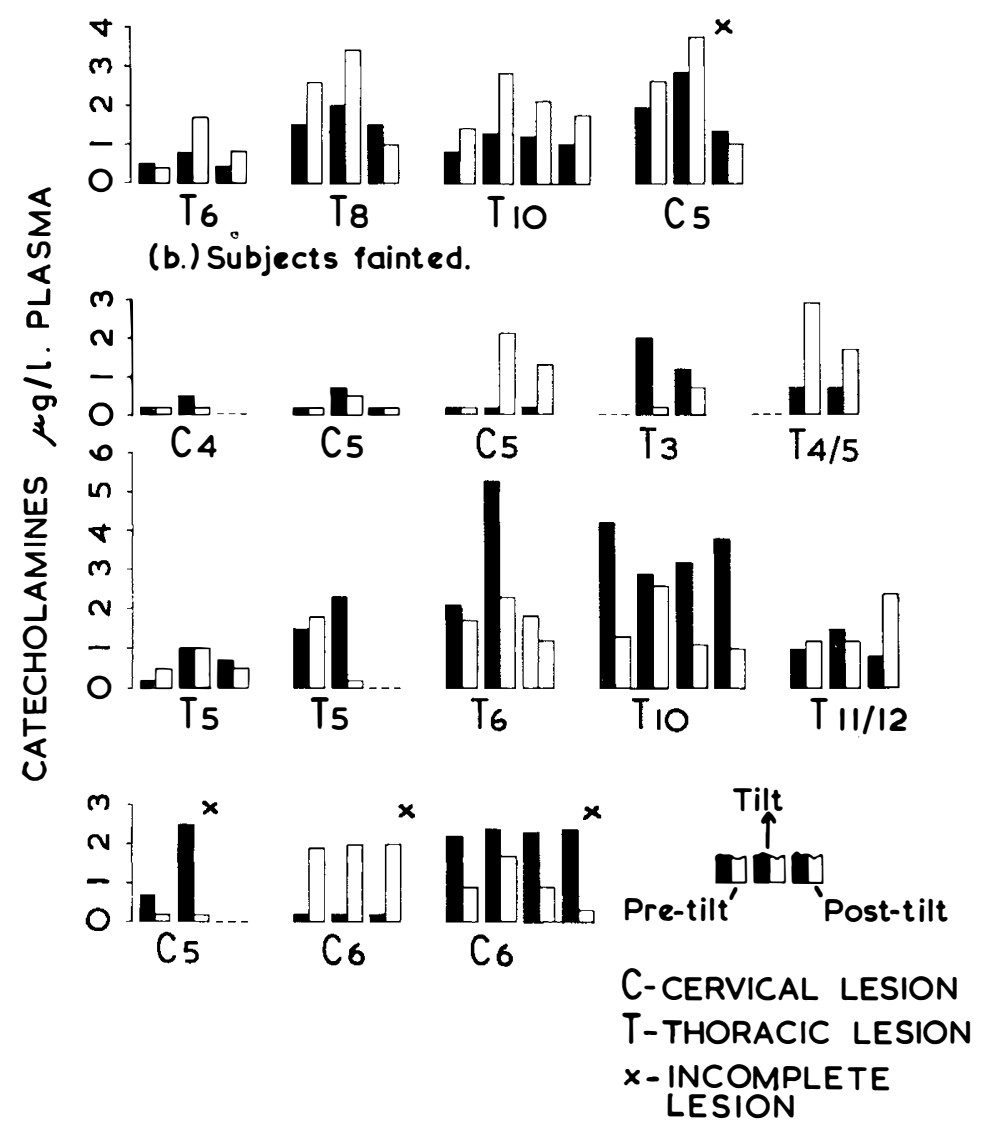

FIG. 4

Shows the adrenaline and noradrenaline values in the peripheral plasma of paraplegic subjects in response to movement vertically on a tilt table. Adrenaline values are shown $\square$ and noradrenaline $\square$. Figure $4(a)$ shows the response of subjects with complete or incomplete lesions tilted and retained in the vertical position for 15 minutes without fainting. Figure $4(b)$ shows the response of subjects with complete or incomplete lesions tilted to the vertical and fainting. $\frac{\mathrm{A}}{\mathrm{B}} \mathrm{C}$ represent the adrenaline and noradrenaline plasma levels in the horizontal pre-tilt position, the vertical position and the post-horizontal position respectively.

fainted after being tilted upright had flaccid paralysis of the lower limbs as a result of a Tio lesion. The other two had the usual extensor tonus with TII and TI2 lesions respectively, but they also developed nausea after the faint and so it is possible that stimuli other than those resulting from the spinal condition may have contributed to the faint. Guttmann (1946) observed that individual patients with high spinal lesions may improve with time and training in the ability to remain erect without fainting, and Jonason (1947) reported improvement of the 
cardiovascular response with time and training in two spinal subjects. In the present investigation six spinal patients were subjected to the tilt test on more than one occasion within the space of a few weeks, but improvement was not invariably found. The complexity of the factors involved is demonstrated by the response of the patient with an incomplete lesion below C6 (fig. I $e$ ) whose voluntary movement of the lower limbs was abolished but who had some slight sensory sparing in $S_{I}, r>1$. She was tilted on three occasions without fainting but twice had an unrecordable blood pressure. Further investigation of this aspect of therapy requires examination over a longer period of a much larger group of subjects using a sensitive and continuous method for recording blood pressure.

From the ECG records the changes in heart rate could be determined precisely during and after the tilting procedure. Only occasionally was irregularity associated with the cardiac acceleration produced by tilting, and there was no evidence of gross functional cardiac abnormality although some records suggested cardiac ischaemia before consciousness was lost. The increase in heart rate was usually maintained until fainting occurred, indicating that the vagal reflex pathway persists under sino-aortic control. The process leading to unconsciousness in the spinal subject would therefore appear to differ from the typical vaso-vagal reaction where bradycardia precedes the faint and tends to persist after recovery of consciousness (Bryden et al., I950). Bradycardia did occur in the spinal subjects after recovery of consciousness, but it was associated with an elevated blood pressure. It is possible that splanchnic vasoconstriction occurs as a result of anoxic stimulation of adrenal medullary activity during the hypotensive state produced by tilting. Although this may be insufficient to maintain the blood pressure in the erect posture it may be enough to raise it above normal when the subject is recumbent, since, in the spinal patient with a high lesion, the only compensatory mechanism available would be cardiac inhibition. In the normal subject the same tendency would be offset by vasodilation as well as cardiac slowing. Bearn et al. (I95I) have shown that a period of splanchnic constriction follows the vasodilation in normal subjects who are induced to faint by cuffing, and have suggested that this might be associated with the secretion of adrenaline and noradrenaline. Our observations on spinal subjects suggest that when fainting occurs the normal plasma catecholamine response to tilting, namely a relative increase in the noradrenaline component, becomes less obvious and adrenaline changes more obvious. A knowledge of the splanchnic blood flow in the spinal subject in these circumstances might make the significance of these changes more clear.

The subjects who did not faint showed changes in heart rate and blood pressure in response to tilting similar to those of normal men (Allen et al., I945). The higher diastolic pressure during the tilt, together with a higher plasma noradrenaline, probably reflects the increase of adrenergic nerve activity and thus the degree of vasomotor control. Similar changes of the urinary catecholamines as a result of tilting normal subjects have been described by Euler and Franksson (1956-57) and Sundin (1958). Hickler et al. (1959) studied subjects with deficient vasomotor control and found plasma noradrenaline values in resting and tilted subjects closely comparable to our own. They used a different method of plasma catecholamine assay which may account for the discrepancy between the plasma adrenaline values. More recently Vendsalu (1960) in a similar investigation found an increase of noradrenaline in the peripheral plasma in response to tilting, but the absolute values were much lower than in the present investigation. 
Since the fluorescence of the trihydroxyindoles was the basis for estimation in both cases we are unable to account for the difference, except that our blood samples were taken into a fluoride thiosulphate solution instead of heparin and the fluorimeters were of different types.

The possibility remains that catechol derivatives of adrenaline and noradrenaline, with comparable fluorescence characteristics, may account for our higher observed values, although the specificity of the method would appear to preclude this possibility. Previous investigations, using this method, indicate that the plasma catecholamine changes in a diversity of physiological states are such as might reflect the expected changes of sympathetic and adrenal-medullary activity; the effect, for instance, of adrenalectomy (Munro \& Robinson, 1960) and graded severity of exercise (Munro \& Robinson, 1958). In the present investigation, it may therefore be significant that the plasma catecholamine changes in the subjects who fainted showed some variation from the type of response consistently observed in the non-fainting group, and that these changes are related in some degree to the ability to maintain the normal level of the blood pressure.

\section{SUMMARY}

Patients with complete and incomplete lesions at different levels of the spinal cord were moved on a tilt table into the erect position. With lesions above T6 fainting occurred in every case except one; with lesions below T6 the incidence of fainting was not much higher than in normal subjects in similar tests.

The response of the heart rate and blood pressure differs in fainting and non-fainting subjects, during tilt and subsequent recumbency; but heart rate and blood pressure changes in the fainting group do not bear much relation to the level of the lesion.

The catecholamine levels of the peripheral plasma were increased in the erect posture in both fainting and non-fainting subjects and the values observed were related to the level and completeness of the lesion. When fainting occurred, the plasma adrenaline value often exceeded the noradrenaline value, but this was not found when consciousness was retained.

The effects of rapid postural change in paraplegics are discussed in relation to the central control of the peripheral vascular bed, and the liberation of noradrenaline from sympathetic nerve-endings.

\section{RÉSUMÉ}

Des malades avec des lésions medullaires, complètes ou incomplètes de niveaux differents, ont été placés sur une table basculante et mis rapidement en position verticale. Chez ceux dont le niveau était supérieur à D6, l'évanouissement s'est produit à chaque fois, excepté dans un cas. Le pourcentage d'évanouissements chez ceux dont le niveau était inférieur à D6 ne différait pas sensiblement de celui de sujets normaux placés dans les mêmes conditions.

La variation du rythme cardiaque et de la tension artèrielle était diffèrente chez les sujets qui s'évanouirent et ceux qui ne le firent pas, en position verticale et ensuite en position horizontale; mais le rythme cardiaque et la T.A. dans le groupe de ceux qui s'évanouirent ne presenta pas de d'analogie avec le niveau de la lésion.

Les valeurs des catecholamines (adrénaline et noradrénaline) dans le plasma périphèrique se trouva augmentée dans la position verticale dans les deux groupes, et, en rapport avec le fait que les lésions étaient complètes ou non.

Quand l'évanouissement se produisit le taux d'adrénaline se trouva souvent superieur à celui de la noradrénaline; ceci ne se retrouva pas chez ceux qui ne s'évanouirent pas. 
Les effets d'un changement rapide de position chez les paraplègiques ont été discutés en relation avec le contrôle d'origine centrale du système vasculaire périphérique et la décharge de noradrénaline aux terminaisons du sympathique.

\section{ZUSAMMENFASSUNG}

Patienten mit kompletten und inkompletten Läsionen in verschiedenen Höhen des Rückenmarks wurden auf einem Dreh-Bett in die aufrechte Körperhaltung gebracht. Bei Läsionen oberhalb von T.6 wurden, mit einer Ausnahme, alle bewusstlos. Bei Läsionen unterhalb T.6 entsprach die Zahl der Ohnmachten der von Nichtgelähmten. Es besteht ein Unterschied in der Reaktion des Pulses und des Blutdrucks zwischen den Patienten, die ohnmächtig wurden, und denen ohne Bewusstseinsverlust, sowohl während des Aufrichtens wie bei der nachfolgenden Lage in der Horizontale. Aber Puls und Blutdruck in der Gruppe mit Bewusstseinsverlust stehen in keinem direkten Verhältnis zu dem Niveau der Lähmung.

Am aufrechten Patienten war der Catecholamin Gehalt des peripheren Plasma's sowohl bei Bewusstlosen wie bei Ungestörten erhöht und die Werte entsprachen dem Niveau und dem Umfang der Läsion. Wenn Bewusstseinsverlust auftrat, war der Adrenalin Gehalt des Plasma oft höher als der Noradrenalin Gehalt. Dies konnte bei den Patienten, ohne Bewusstseinsverlust, nicht beobachtet warden.

Der Einfluss schneller Lage-Änderung am Querschnittsgelähmten wird im Zusammenhang mit der zentralen Kontrolle des peripheren Gefässbettes besprochen sowie die Befreiung von Noradrenalin von sympathischen Nervenendigungen.

\section{REFERENCES}

Allen, S. C., Taylor, C. L., \& Hall, V. E. (1945). Amer. F. Physiol., r43, I I.

Bearn, A. G., Billing, B., Edholm, O. G., \& Sherlock, S. (I9I5). F. Physiol., I15, 442. Bryden, W., Howarth, S., \& Sharpey-Schafer, E. P. (I950). Clin. Sci., 9, 79.

Crawford, T. B. B., \& Gutschoorn, A. S. (I95I). Brit. F. Pharmacol., 6, I8.

Cunningham, D. J. C., Guttmann, L., Whitteridge, D., \& Wyndham, C. H. (I953), F. Physiol., I2I, 58I.

Euler, U. S. von, \& Floding, I. (1955). Acta physiol. scand., 33, Suppl. ri 8, 45.

Euler, U. S. von, \& Franksson, C. (I956-57). Acta physiol. scand., 38-39, 275.

Gaddum, J. H., \& Lemback, F. (I949). Brit. F. Pharmacol., 4, $40 \mathrm{I}$.

Guttmann, L. (1946). Brit F. Phys. Med., 9, I62.

Guttmann, L. (1953). In History of the Second World War, United Kingdom Medical Series. Surgery, p. 422, ed. Cope, Sir Zachary. London: H.M.S.O.

GutTMANN, L., \& WhitTeRidge, D. (I947). Brain, 70, 36I.

Hickler, R. B., Wells, R. E., Tyler, H. R., \& Hamlin, J. T. (1959). Amer. F. med. Sci., 26, 4 IO.

Hill, L. (1895). F. Physiol., 18, I5.

Jalon, P. G. DE, Bayo, J. B., \& Jalon, M. G. DE (1945). Farm. Deta, 2, 313.

Jefrers, W. A., Montgomery, H., \& Burton, A. C. (I94I). Amer. F. med. Sci., 202, I.

Jonason, P. (1947). Proc. R. Soc. Med., 40, 226.

Munro, A. F., \& Robinson, R. (1958). F. Physiol., r43, $20 \mathrm{P}$.

Munro, A. F., \& Robinson, R. (1960). F. Physiol., I54, 244.

Sundin, T. (1958). Acta med. scand., r6r, Suppl. 336.

Vendsalu, A. (1960). Acta physiol. scand., 49, Suppl. 173, 70.

Weil-Malmerbe, H., \& BONE, A. D. (1952). Biochem. F., 5I, 3 II I.

Weil-Malherbe, H., \& Bone, A. D. (I958). Biochem. F., 70, I4. 